\title{
Monitoring the Risk of Corruption at International Level: The Case of the United Nations Sustainable Development Goals
}

\author{
Giulia MUGELLINI and Jean-Patrick VILLENEUVE*
}

\section{INTRODUCTION}

The 2030 Agenda for Sustainable Development, ${ }^{1}$ adopted by the United Nations General Assembly on 25 September 2015, identifies 17 goals to be achieved by Member States by 2030 . In order to monitor the progress of Sustainable Development Goals (SDGs) and the corresponding targets, the United Nations Statistical Commission identified and approved a global framework of indicators. ${ }^{2}$

The Agenda, with its goals, targets and indicators, plays a role of prime importance in defining, classifying and measuring the most pressing risks faced by the global community today. It helps structure these risks as well as providing guidance and incentives to address them. In doing so, a number of challenges emerge. Finding the right indicator(s) for monitoring SDGs at national level is among the main challenges of the 2030 Agenda. The international community is recognising the need to use national indicators, based on national priorities, and trying to align them to global SDGs indicators. ${ }^{3}$ However, with regard to specific phenomena, data at national level might not be consolidated and reliable enough, and in some cases not even available. This is especially true when considering complex and transversal issues such as corruption (Target 16.5).

Corruption entails several types of behaviors, affects a variety of actors and, at the same time, is characterised by a hidden and collusive nature. For these reasons, defining, classifying and measuring this phenomenon is not an easy task. Even if considerable progress has been recently made in order to improve its measurement, ${ }^{4}$ a comprehensive and standardised measure of corruption is still missing. This issue inevitably impedes both the proper monitoring of the risk of corruption and effectively responding to SDGs'

* Institute for Public Communication, Faculty of Communication Sciences, Università della Svizzera italiana (USI).

1 United Nations General Assembly Resolution 70/1, Transforming our World: the 2030 Agenda for Sustainable Development, A/RES/70/1, 21 October 2015.

2 Report of the Inter-Agency and Expert Group on Sustainable Development Goals Indicators (E/CN.3/2017/2*).

3 ibid.

4 S Sequeira, "Advances in Measuring Corruption in the Field" in S Sequeira, New Advances in Experimental Research on Corruption (2012), ch 6, published online 9 March 2015, p 145; A Mungiu-Pippidi and R Dadašov, "Measuring Control of Corruption by a New Index of Public Integrity" (2016) 22 European Journal on Criminal Policy and Research 415. 
requirements (Target 16.5). It also impedes the proper development of counter-measures to confront this phenomenon.

This report critically discusses how the SDG indicators for monitoring corruption have been defined by the 2030 Agenda, and how their practical implementation has been supported by international agencies. It identifies the main problems in implementing these efforts and considers what could be done further to support countries complying with SDG requirements on corruption. Corruption is an interesting test-case to better understand the more general challenges facing the concerted attempt to address current risks as well as possible paths to mitigate their impact.

\section{Sustainable DEVElopment GOALS AND CORRUPTION}

The 2030 Agenda for Sustainable Development recognises corruption as an obstacle for sustainable development and devotes one specific target to this issue. In particular, under the umbrella of Goal 16 to "Promote peaceful and inclusive societies for sustainable development, provide access to justice for all and build effective, accountable and inclusive institutions at all levels", Target 16.5 aims to "Substantially reduce corruption and bribery in all their forms". The reduction of corruption is considered one of the most important steps to pave the way for sustainable development and to promote inclusive societies by building effective, accountable and inclusive institutions at all levels.

In order for national governments and international organisations to monitor the reduction of public sector corruption, the United Nations Statistical Commission identified two indicators, one for persons (16.5.1) and one for businesses (16.5.2). Indicator 16.5.1 refers to the "Proportion of persons who had at least one contact with a public official and who paid a bribe to a public official, or were asked for a bribe by those public officials, during the previous 12 months". 6 Indicator 16.5 .2 concerns the "Proportion of businesses who had at least one contact with a public official and who paid a bribe to a public official, or were asked for a bribe by those public officials, during the previous 12 months". 7

According to the analysis presented in Table 1 below, the SDG indicators suggest monitoring the level of corruption by measuring both active ${ }^{8}$ and passive $e^{9}$ bribery in the public sector (involving public officials), experienced by persons and businesses, during a reference period of 12 months, and measured as the prevalence of those who had at least one contact with a public official.

\footnotetext{
5 See supra, note 2.

6 ibid.

7 ibid.

8 According to the UN Convention Against Corruption (2004), active bribery is defined as: "Promising, offering or giving, to a public official or a person who directs or works in a private sector entity, directly or indirectly, an undue advantage in order so that the official acts or refrains from acting in the exercise of his or her official duties" (Art 15).

9 According to the UN Convention Against Corruption (2004), passive bribery is defined as: "Solicitation or acceptance by a public official or a person who directs or works in a private sector entity, directly or indirectly, of an undue advantage in order so that the official acts or refrain from acting in the exercise of his or her official duties" (Art 15).
} 
Table 1. SDG indicators on corruption - key elements

\begin{tabular}{ll}
\hline $\begin{array}{c}\text { 1. Type of } \\
\text { corruption }\end{array}$ & $\begin{array}{c}\text { Bribery in the public sector (“.... at least one contact with a public official...”). } \\
\text { Active bribery (“.... who paid a bribe...”) and passive bribery (“.... were asked for a } \\
\text { bribe...”). }\end{array}$ \\
$\begin{array}{c}\text { 2. Type of } \\
\text { counterpart }\end{array}$ & Public officials \\
$\begin{array}{c}\text { 3. Target } \\
\text { population }\end{array}$ & Persons \\
$\begin{array}{c}\text { 4. Reference } \\
\text { period }\end{array}$ & Businesses \\
$\begin{array}{c}\text { 5. Type of } \\
\text { prevalence }\end{array}$ & Prevalence of those who had contacts with public officials \\
\end{tabular}

Source: authors' elaboration of SDG indicators on corruption

\section{SDG INDICATORS TO MONITOR THE RISK OF CORRUPTION: THE CURRENT DEGREE} OF IMPLEMENTATION

To evaluate the degree of implementation of the global indicator framework, the Interagency and Expert Group on SDG Indicators (IAEG-SDGs) periodically classifies SDG indicators into three tiers on the basis of their level of methodological development and data availability across Member States. Indicators belonging to Tier 1 are conceptually clear, have an internationally established methodology and standards are available, and data are regularly produced for at least $50 \%$ of countries and of the population in every region where the indicator is relevant. Indicators belonging to Tier 2 are conceptually clear, have an internationally established methodology and standards are available, but data are not regularly produced by countries. Indicators belonging to Tier 3 do not have internationally established methodology or standards, but methodology/standards are being (or will be) developed or tested. ${ }^{10}$

The tier classification is updated every two months by the IAEG-SDGs. The last update of the tier classification was run in February 2019.

According to the last update, both indicators 16.5.1 and 16.5.2 belong to the second tier, meaning that internationally established methodology and standards to measure bribery in the public sector among both persons and businesses are available, but data are not regularly produced by countries. Indicator 16.5.2 was initially classified as Tier 1 and upgraded to Tier 2 by the IAEG-SDGs members in March 2016.

\section{EXISTING INTERNATIONAL GUIDANCE ON HOW TO PRODUCE PRIMARY DATA TO MONITOR TARGET 16.5 ON CORRUPTION}

The lack of data on corruption is related to the multifaceted nature of this phenomenon, which impedes the use of official statistics and requires additional resources for the development of dedicated data collections in order to obtain more reliable information.

10 See < unstats.un.org/sdgs/iaeg-sdgs/tier-classification/>. 
Measuring corruption is a complex task, mainly due to its hidden and consensual, collusive, nature. Due to these characteristics, corruption is rarely reported to the relevant authorities and/or discovered by the police. As a consequence, official crime statistics on reported cases of corruption suffer from a very high "dark figure". ${ }^{11}$ Around $74 \%$ of corruption cases experienced by citizens across European Member States are not reported to the relevant authorities. ${ }^{12}$ Official/administrative data on corruption provide information about the activity and response of criminal justice systems rather than the extent of this phenomenon on the ground. In response to this issue, sample surveys represent one of the main attempts to complement official data in measuring this phenomenon in a direct way. Indirect measurements tools are also available (eg composite indices and experts' assessment ${ }^{13}$ ) but present several weaknesses in terms of validity and relevance (eg subjective interpretation of corruption, lack of disaggregated data and information, etc).

The use of sample surveys would also answer the quality standards requested for SDG indicators. The United Nations Statistical Commission calls for data that are collected through a rigorous methodology, that are publicly accessible (publicly, freely available), regularly generated and comparable over time, and reliable. Furthermore, sample surveys allow the gathering of micro-level data which allow for an analysis of data at the highest level of disaggregation - the crime incident and its victim. ${ }^{14}$ They also permit covering different populations (eg individuals, households, businesses, civil servants), which is of utmost importance to understanding how corruption types and risks change among different actors.

The number of UN Members States developing sample surveys on corruption on a regular basis is still limited. ${ }^{15}$ The main reasons for the scarcity of sample surveys are related to their very high costs and to the lack of standard methodological guidance. ${ }^{16}$

Drawing on the need to monitor Target 16.5 on corruption, and provide Member States with support for strengthening data collection and capacity building on this issue, the United Nations Office on Drugs and Crime (UNODC), the United Nations Development Programme (UNDP) and the UNODC-INEGI Center of Excellence in Statistical Information on Government, Crime, Victimization and Justice developed a manual for measuring corruption through sample surveys. The project started at the beginning of 2016 and was completed at the end of 2018 with the publication of the Manual. $^{17}$

\footnotetext{
11 The difference between the number of crimes experienced by a specific subject in a specific context and the number of officially recorded crimes (by relevant authorities) in that context.

12 European Commission, Special Eurobarometer 397. Corruption. Wave EB79.1 - TNS Opinion \& Social (European Commission 2014).

13 UNODC, UNDP and the UNODC-INEGI Center of Excellence in Statistical Information on Government, Crime, Victimization and Justice, Manual on Corruption Surveys (Vienna 2018).

14 L Neuman and RJ Berger, "Competing Perspectives on Cross-National Crime: An Evaluation of Theory and Evidence" (1988) 29(2) The Sociological Quarterly 281; JP Lynch, "Secondary analysis of international crime survey data" in A Alvazzi del Frate et al (eds), Understanding Crime: Experiences of Crime and Crime Control (Rome, UNICRI 1993); JP Lynch, "Problems and Promise of Victimization Surveys for Cross-National Research" (2006) 34(1) Crime and Justice 229.

15 Existing corruption surveys have been stored in the UNODC-INEGI Center of Excellence, Repository of Corruption Measurement Tools.

16 Manual on Corruption Surveys, supra, note 13.
} 
The development of the Manual was supported by the creation of a repository of information on existing data measurement tools on corruption. ${ }^{18}$ The characteristics of more than a hundred sample surveys on corruption were collected and analysed in order to support and inform the content of the Manual. Furthermore, a UN Task Force on the measurement of corruption was created. The Task Force includes 21 members representing national statistical institutes, international organisations, private agencies and academics dealing with the measurement of corruption. The Manual is primarily targeted at national statistical agencies, in order for them to develop a specific measurement tool on corruption that can become an integral part of their data collection system.

\section{MAIN PITfalls OF SDG INDICATORS IN MONITORING CORRUPTION AND SUGGESTIONS FOR FUTURE INITIATIVES}

\section{Corruption definitions}

Target 16.5 on corruption aims to "Substantially reduce corruption and bribery in all their forms". ${ }^{19}$ However, the indicators suggested by the United Nations Statistical Commission to monitor the reduction of corruption across Members States refer to only one form of corruption: bribery in the public sector.

It is widely recognised that corruption goes beyond bribery and involves a large number of different aspects. According to the UN Convention Against Corruption, ${ }^{20}$ Member States should recognise as corruption the following offences: bribery (active and passive) of national public officials (Art 15); bribery of foreign public officials and officials of public international organisations (Art 16); embezzlement, misappropriation or other diversion of property by a public official (Art 17); trading in influence (Art 18); abuse of functions (Art 19); illicit enrichment (Art 20); bribery in the private sector (Art 21 ); embezzlement of property in the private sector (Art 22); laundering of proceeds of crime (Art 23); concealment (Art 24); obstruction of justice (Art 25).

When designing systems for monitoring corruption, countries should be aware that SDG indicators concern only one aspect of the corruption problem (ie bribery). In order to develop a comprehensive system for evaluating the occurrence of corruption, the other conducts that are criminalised by the UNCAC might also be taken into consideration. The main issue with these additional offences relates to the difficulties in measuring them.

The focus on bribery in the public sector reflects one of the main pitfalls of the current anti-corruption approach, the overwhelming focus on the characteristics of developing countries for problematising corruption. Indeed, types of corruption linked to tangible gains, such as bribery, are those mainly affecting developing countries, while developed countries are mainly experiencing those linked to favouritism and lobbying. ${ }^{21}$

17 See < www.unodc.org/documents/data-and-analysis/Crime-statistics/CorruptionManual_2018_web.pdf > .

18 UNODC-INEGI Center of Excellence, Repository of Corruption Measurement Tools.

19 See supra, note 2.

20 UN Convention against Corruption (UNCAC) (United Nations, New York, 2004), available at < www.unodc.org/ documents/treaties/UNCAC/Publications/Convention/08-50026_E.pdf > .

21 A Graycar and O Monaghan, "Rich Country Corruption" (2015) 38(8) International Journal of Public Administration 586, available at < doi.org/10.1080/01900692.2014.949757> . 
The UN Manual on Corruption Surveys suggests questions to be included in sample surveys in order to estimate the presence of other forms of corruption rather than bribery in the public sector, for example, experiences of bribery in the private sector, experiences of nepotism and/or cronyism, experiences of vote buying. ${ }^{22}$ However, dedicated guidelines on how to measure other forms of corruption, as defined by the UNCAC, are still missing and should be considered an important step toward the improvement of corruption monitoring and the support of SDGs implementation.

\section{Proxies of corruption}

The SDG indicators on corruption suggest that experiences of bribery should be measured, but its perception is currently not considered. One of the central distinctions in measuring corruption focuses on the differences between experienced and perceived corruption. They have different causes and consequences and should be studied as two complementary dimensions of the same phenomenon. ${ }^{23}$ Experienced corruption refers to people's direct experience with or participation in corruption and it is influenced by people's interaction with bureaucrats or the government. ${ }^{24}$ In particular, it concerns three main cases: observing a bribe being paid/a favour or gift being provided, paying a bribe/ providing a favour or gift, or having been asked to pay a bribe/provide a favour or gift. ${ }^{25}$ Perceived corruption concerns the level of corruption an individual believes to exist. ${ }^{26}$ These beliefs are influenced by the nature of the political system and public institutions, and by the attitudes of other individuals. Perceived corruption is thus more sensitive to scandals, press reports, and even political rhetoric, than experience of corruption. ${ }^{27}$ However, it still represents an important aspects of the corruption problem to be measured because it frequently reflects the presence of broader range of attitudes and beliefs (for example, conflict of interest, abuse of power, embezzlement of public funds, etc). ${ }^{28}$

The UN Manual on Corruption Surveys recognises the importance of measuring also the perception of corruption in order to have a more comprehensive overview of the phenomenon, and it suggests how to formulate questions to address this issue. In particular, it suggests how to measure the perception of corruption in relation to specific administrative procedures, specific public officials and selected situations. $^{29}$

\footnotetext{
22 Manual on Corruption Surveys, supra, note 13, pp 138-140.

23 SD Morris, "Disaggregating Corruption: A Comparison of Participation and Perceptions in Latin America with a Focus on Mexico" (2008) 27(3) Bulletin of Latin American Research 388.

24 ibid.

25 MA Seligson, "The Impact of Corruption on Regime Legitimacy: A Comparative Study of Four Latin American Countries" (2002) 64(2) Journal of Politics 408.

26 Morris, supra, note 23.

27 ibid.

28 Manual on Corruption Surveys, supra, note 13, 142-143.

29 GO Erlingsson and GH Kristinsson, "Making Sense of Corruption Perceptions: Who to Ask (and About What?) Evidence from Iceland” (2016) 13 QoG Working Paper Series; Manual on Corruption Surveys, supra, note 13.
} 


\section{Corruption measurement}

The UN Manual on Corruption Surveys represents the first guide developed by an international organisation with the purpose of supporting national government in collecting primary data for monitoring Target 16.5 on corruption. ${ }^{30}$ This effort responds to the need to build countries' capacity to produce metrics of corruption at national level that are also comparable at international level, and to integrate them into national official statistics. In order for the Manual to be usable by practitioners and members of national statistical offices, translations into the main UN official languages might be envisaged, together with practical on-site courses. This would support the adoption of the suggested methodological guidelines by national agencies.

The Manual addresses only one method for measuring corruption: sample surveys. ${ }^{31}$ Other methodological approaches for measuring corruption are available and might also be more suitable for monitoring specific forms of corruption (eg embezzlement of public goods). Methodologies are being developed in this regard and mainly concern the use of big data (procurement data, fiscal government data, financial disclosures and audits) and the creation of indirect, objective indicators. ${ }^{32}$ These indicators are particularly efficient in identifying vulnerabilities to corruption, but they might run the risk of reflecting institutional capacity gaps. ${ }^{33}$ Another approach to the measurement of corruption concerns the use of news articles. In this case, reliability issues are mainly related to the fact that countries have different degrees of press freedom or repression. ${ }^{34}$

Dedicated guidelines on how to use these additional corruption measures would be necessary. These guidelines should clarify what types of corruption are best represented by a specific indicator, how to create the indicator (which data sources and variables should be used, where they could be found and how they should be combined), and what caveats should be considered when analysing the results.

Additional efforts should also be invested in order to understand whether data on different SDGs and Targets can be collected through the same tool. For example, a sample survey on corruption can be used to monitor Target 16.5, but also Target 16.6 on the development of effective, accountable and transparent institutions at all levels, or Target 16.10 on the promotion of public access to information and protection of fundamental freedoms in accordance with national legislation and international agreements.

In order to more effectively address the other 169 targets identified by the 2030 Agenda, one needs to take note of the challenges identified here, notably those related to the proper identification, classification and measurement of the risk phenomena under study. Despite the broad variety of policy fields and sectors of intervention present across SDGs, the decisions regarding the way in which a particular risk is approached will go a long way in determining what is done and not done in order to mitigate it.

\footnotetext{
30 Transparency International developed a guide on "Monitoring Corruption and Anti-Corruption in the Sustainable Development Goals: a Resource Guide" in 2017. However, that guide aims to explain the role of civil society organisations in monitoring corruption in the SDGs. It provides examples of potential indicators and data sources for this purpose but it does not offer guidelines for developing specific data collections at national level.

31 Manual on Corruption Surveys, supra, note 13, pp 26-29.

32 Mungiu-Pippidi and Dadašov, supra, note 4.

33 S Hlatshwayo et al, "The Measurement and Macro-Relevance of Corruption: A Big Data Approach" (2018) International Monetary Fund (IMF) Working Papers.

34 ibid.
} 